\title{
Secretory IgA: immune defence pattern in ankylosing spondylitis and klebsiella
}

\author{
M. CALGUNERI, ${ }^{1}$ L. SWINBURNE, ${ }^{2}$ R. SHINEBAUM ${ }^{3}$ E. M. COOKE, ${ }^{3}$ AND \\ V. WRIGHT ${ }^{1}$
}

From the ${ }^{1}$ Rheumatism Research Unit, University Department of Medicine, General Infirmary at Leeds; the ${ }^{3}$ Department of Microbiology, University of Leeds; and the ${ }^{2}$ Department of Immunology, St James's University Hospital, Leeds

SUMMARY Saliva secretory IgA (sIgA), secretory component (SC); serum immunoglobulins (IgG, IgA, IgM), complement $\left(\mathrm{C}_{3}, \mathrm{C}_{4}\right)$, C-reactive protein (CRP), and erythrocyte sedimentation rate (ESR) were performed in 32 patients with ankylosing spondylitis and 29 normal controls. They were investigated for carriage in the faeces of Klebsiella spp. on 3 occasions over the previous months. Throat swabs and urine were cultured at the same time as immunological estimations were done. 24-hour urine sIgA specimens were studied in 13 patients and 12 normal controls. Significantly raised mean values of saliva $\operatorname{sgA}$ and serum $\operatorname{IgG}, \operatorname{IgA}, \mathrm{C}_{3}$, and $\mathrm{C}_{4}$ were found in patients with raised values of serum ESR and CRP levels when correlated with controls. Raised values of SIgA in saliva, which is an important factor of the local immune defence mechanism of mucosal surfaces, suggests the presence of an antigenic stimulus from the gastrointestinal system in ankylosing spondylitis during activity of disease.

An infective aetiology for ankylosing spondylitis (AS), especially an association with genitourinary infection has been postulated for many years. ${ }^{1-4}$ More recently an increased isolation of klebsiella from the faeces of AS patients during active phases of disease has been reported, ${ }^{56}$ though others have not been able to confirm these results. ${ }^{7}$ The Leeds group has demonstrated the association in these patients to be particularly marked in those with uveitis. $^{8}$

The association between AS and HLA B2 $7^{9} 10$ has led many workers to suggest that the pathogenesis of AS might involve immune response genes, although as yet no disease susceptibility locus or immune response gene has been identified.

Raised levels of serum $\operatorname{IgA}$ and $\mathrm{C}_{4}$ in patients with AS have been reported. ${ }^{11}$ Individuals with HLA B27 positive AS have higher mean serum concentrations of IgG and IgA than normal controls $^{12}$ and than their B27 positive and negative relatives. $^{13}$

In human serum IgA is $85 \%$ monomeric, $10-15 \%$ polymeric, and $1 \%$ sIgA. sIgA levels tend to rise in patients with a variety of mucosal inflammatory

Accepted for publication 16 January 1981.

Correspondence to Professor V. Wright, Rheumatism Research Unit, School of Medicine, 36 Clarendon Road, Leeds LS2 9PJ. diseases. ${ }^{14}$ In man monomer is synthesised mainly in nonmucosal lymphoid tissues, while both sIgA and polymeric $\operatorname{IgA}$ come from mucosal sites, especially the gut, ${ }^{15}$ which has an integral and important role in the immune defence of the gastrointestinal tract.

$\operatorname{sIg} \mathrm{A}$ is the predominant immunoglobulin in secretory fluids of the body. It has been shown that this immunoglobulin is found in milk, saliva, tears, urine, cervicovaginal fluids, amniotic fluids, and gastrointestinal secretions. ${ }^{1617}$

The IgA molecule in external secretions has several features that distinguish it from its serum counterpart. Serum IgA in man is predominantly a 7S monomer (molecular weight 160000 ), while the sIgA is an $11 \mathrm{~S}$ dimer (molecular weight 400000 ) consisting of 2 units of $7 \mathrm{~S} \operatorname{IgA}$ together with 2 nonimmunoglobulin components, 'secretory component' (molecular weight 70000 ) and a ' $\mathrm{J}$ ' chain (molecular weight 15000$) .18$

This report is concerned with an investigation into the nature of the local immune defence system in ankylosing spondylitis.

\section{Patients and methods}

Thirty-two outpatients with ankylosing spondylitis and 29 normal controls have entered the study. 
Table 1 shows the age and sex distribution of the patients and controls. The diagnosis of AS was made by the New York criteria. ${ }^{19}$ Three patients did not have the HLA B27 antigen and the test was not performed in 4 cases. Patients with inflammatory bowel disease and Reiter's disease were excluded. Controls were selected from medical staff and other volunteers.

All patients and controls had been asked to post a stool specimen passed within the previous 24 hours on 3 occasions over a 2 -month period with 4 -week intervals. Each patient filled in a diary over the time of the study to assess anti-inflammatory drug requirement, duration of early morning stiffness, severity of back pain, peripheral joint symptoms, eye symptoms, and any infectious disease or antibiotic therapy. All controls were provided with a special questionnaire to indicate any infectious disease or antibiotic therapy over the same period.

At the end of 2 months patients and controls were called to a special clinic for collection of saliva, blood, midstream specimen of urine, and throat swab between $1 \mathrm{pm}$ and $4 \mathrm{pm}$. Assessment of clinical disease activity of patients was based on the criteria which have been described before. ${ }^{8}$

\section{SALIVA SAMPLES}

Parotid saliva was collected by using modified Curby cups ${ }^{20}$ from the right side in the majority of cases. (These cups were specially made for the study by the Department of Oral Biology, Dental School, Leeds.) Saliva was stimulated by approximately $10 \mathrm{ml} 10 \%$ citric acid at the beginning of the collection. $10 \mathrm{ml}$ of saliva was collected from all except 3 patients, including the first $0.5 \mathrm{ml}$ unstimulated specimen which was present in the parotid duct prior to the stimulation. No sodium azide preservatives were added, but the samples were immediately stored at $-20^{\circ} \mathrm{C}$.

All samples were concentrated 25 and 50 times in Minicon B15 concentrators (Amicon Corporation). The levels of $\operatorname{sIgA}$ in the saliva were estimated by a modified single radial immunodiffusion technique ${ }^{21}$ using Dako commercially available antiserum (Dako rabbit IgS to colostrum IgA- $\alpha$ chain and secretory piece). Hoechst radial immune diffusion plates were used as templates. $5 \cdot 2 \mathrm{ml}$ of $1 \%$ agarose in barbitone acetate buffer and $110 \mathrm{ml}$ antiserum were used to pour on the plates. Wells were punched with a $2 \mathrm{~mm}$ diameter well punch and filled with a $5 \mu$ i volume of

Table 1 Age and sex of patients and controls

\begin{tabular}{llll}
\hline \multicolumn{1}{c}{$n$} & Male & Female & Mean age range in years \\
\hline Patients 32 & 28 & 4 & $42 \cdot 41(25-61)$ \\
Controls 29 & 26 & 3 & $36.07(23-65)$ \\
\hline
\end{tabular}

specimen. Hoechst standard human sera were used as standards. A correction was made by a factor $(1 \cdot 72)$ for the slower mobility of $11 \mathrm{~S}$ salivary $\operatorname{IgA}$ as compared to the $7 \mathrm{~S}$ serum IgA of the standards. ${ }^{22}$ SC levels in the saliva were measured by single radial immunodiffusion technique. ${ }^{23} 400 \mu \mathrm{l}$ concentration of Nordic commercially available antisera (antisecretory piece-free and bound-produced in sheep) were used. Plates were prepared in the same way as described for sIgA. No standards were used for SC estimation.

\section{URINE SAMPLES}

24-hour urine samples were collected from 13 patients and 12 controls for $\operatorname{sIgA}$ estimation. Samples were dialysed in Visking $36 / 32$ membranes in the cold and were concentrated 1000 times by the use of a freeze-dryer. ${ }^{24}$ All samples were stored at $-70^{\circ} \mathrm{C}$ until used. No 24 -hour specimen of urine contained more than $80 \mathrm{mg}$ of protein by folin or biuret reactions.

The levels of $\operatorname{sIg} \mathrm{A}$ in the urine were carried out by the same method as was used for saliva sIgA.

\section{SER UM SAMPLES}

Serum IgG, IgM, and $\mathrm{C}_{3}$ and $\mathrm{C}_{4}$ estimations were determined by the radial immunodiffusion technique with commercially available immunodiffusion plates and protein standards (Behringwerke-Marburg). Serum ESR was measured by the Westergren method. The normal hospital service was used. Serum CRP estimations were determined by the radial immunodiffusion technique at the Clinical Pharmacology Unit, Royal Bath Hospital.

\section{BACTERIOLOGY}

All faecal samples, urines, and throat swabs were cultured on MacConkey inositol carbenicillin agar (MIC) and citrate agar plates and in citric broth. The broths were subcultured to MIC and citrate agar plates after incubation for 48 hours. Klebsiella spp. were identified as previously. ${ }^{25}$ Throat swabs were also cultured on blood agar and then examined for the presence of beta-haemolytic streptococci.

\section{Results}

SER UM

The results of serum mean $\operatorname{IgG}, \operatorname{IgA}, \operatorname{IgM}, \mathrm{C}_{3}$, and $\mathrm{C}_{4}$ estimations are shown in Table 2. The mean serum IgA, $C_{3}$, and $C_{4}$ levels in AS patients were significantly higher than in normal controls. There was a slight rise in mean serum IgG and $\operatorname{IgM}$ estimations in AS patients when compared with normal controls, but this difference was not statistically significant. 
602 Calguneri, Swinburne, Shinebaum, Cooke, Wright

Table 2 Mean $( \pm S D)$ serum immunoglobulins and $C_{3}$ and $C_{4}$ levels in normal controls and $A S$ patients

\begin{tabular}{|c|c|c|c|c|c|}
\hline \multirow[b]{2}{*}{$\begin{array}{l}\text { Serum } \\
\text { protein }\end{array}$} & \multicolumn{2}{|l|}{ Controls } & \multicolumn{2}{|l|}{ As patients } & \multirow[b]{2}{*}{$\begin{array}{l}\text { Statistical } \\
\text { significance }\end{array}$} \\
\hline & $\begin{array}{l}\text { Mean } \pm S D \\
g / l\end{array}$ & $\begin{array}{l}\text { Number of } \\
\text { estimations }\end{array}$ & $\begin{array}{l}\text { Mean } \pm S D \\
g / l\end{array}$ & $\begin{array}{l}\text { Number of } \\
\text { estimations }\end{array}$ & \\
\hline $\begin{array}{l}\text { IgG } \\
\text { IgA }\end{array}$ & $\begin{array}{r}11 \cdot 07 \pm 3.41 \\
1 \cdot 83 \pm 0.64\end{array}$ & $\begin{array}{l}28 \\
28\end{array}$ & $\begin{array}{r}13 \cdot 83 \pm 7 \cdot 48 \\
2 \cdot 62 \pm 1 \cdot 34\end{array}$ & $\begin{array}{l}32 \\
32\end{array}$ & $\begin{array}{l}\mathrm{NS} \\
\mathrm{P}<0.01 \\
t=2.83\end{array}$ \\
\hline $\begin{array}{l}\text { IgM } \\
\mathbf{C}_{3}\end{array}$ & $\begin{array}{l}1 \cdot 13 \pm 0 \cdot 38 \\
0.84 \pm 0 \cdot 22\end{array}$ & $\begin{array}{l}28 \\
28\end{array}$ & $\begin{array}{l}1.35 \pm 0.62 \\
1.04 \pm 0.35\end{array}$ & $\begin{array}{l}32 \\
32\end{array}$ & $\begin{array}{l}\text { NS } \\
0.02>\mathrm{p}>0.01 \\
t=2.62\end{array}$ \\
\hline $\mathrm{C}_{4}$ & $0.25 \pm 0.09$ & 28 & $0 \cdot 34 \pm 0 \cdot 14$ & 32 & $\begin{array}{l}P<0.01 \\
t=2.85\end{array}$ \\
\hline
\end{tabular}

Table 3 Serum mean $( \pm S D) \operatorname{IgG}, \operatorname{IgA}, C_{3}$, and $C_{4}$ levels in normal controls compared with $A S$ patients with raised ESR and CRP levels

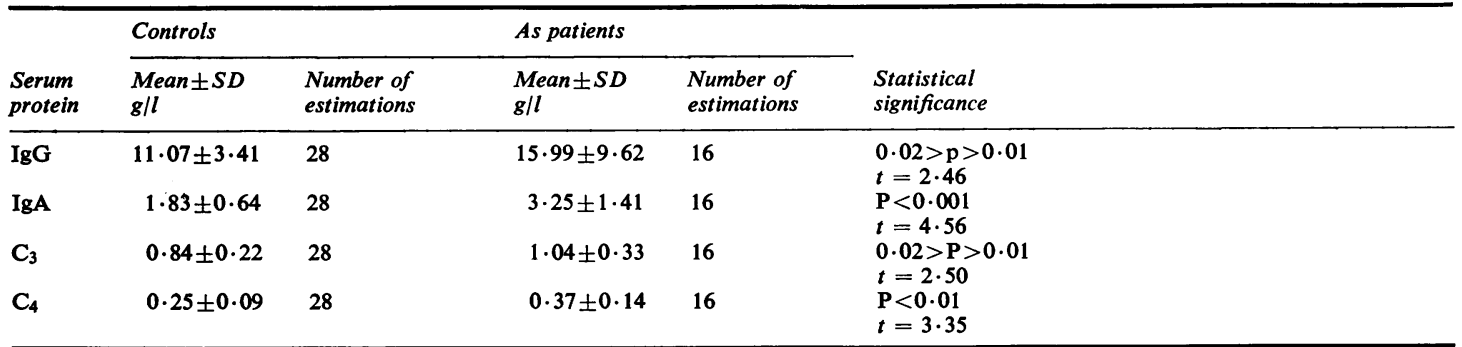

The increases in serum IgG, IgA, $\mathrm{C}_{3}$, and $\mathrm{C}_{4}$ estimations in AS patients were seen even more strikingly in those with raised serum ESR and CRP levels (Table 3).

\section{SALIVA}

The results of mean saliva SIgA and SC estimations are shown in Table 4 . There was a slight rise in mean saliva SIgA and SC estimations in AS patients when compared with normal controls, but this difference was not statistically significant. The patients were divided into 2 groups according to their serum ESR and CRP levels. Saliva SIgA and SC in AS patients with raised ESR and CRP levels was significantly higher than the other group, but the difference was statistically significant only for sIgA (Table 5).

\section{URINE}

The mean urine $\operatorname{sIg} \mathrm{A}$ in AS patients was $2 \cdot 26$

Table 4 Mean ( $\pm S D)$ saliva sIgA and SC levels in normal controls and AS patients

\begin{tabular}{|c|c|c|c|c|c|}
\hline \multirow[b]{2}{*}{$\begin{array}{l}\text { Parotid } \\
\text { secretion }\end{array}$} & \multicolumn{2}{|l|}{ Controls } & \multicolumn{2}{|l|}{$A S$ patients } & \multirow[b]{2}{*}{$\begin{array}{l}\text { Statistical } \\
\text { significance }\end{array}$} \\
\hline & $M e a n \pm S D$ & $\begin{array}{l}\text { Number of } \\
\text { estimations }\end{array}$ & $M e a n \pm S D$ & $\begin{array}{l}\text { Number of } \\
\text { estimations }\end{array}$ & \\
\hline $\begin{array}{l}\text { sIgA (mg/dl) } \\
\text { SC (d2) }\end{array}$ & $\begin{array}{c}4 \cdot 33 \pm 1 \cdot 71 \\
60 \cdot 73 \pm 17 \cdot 58\end{array}$ & $\begin{array}{l}29 \\
29\end{array}$ & $\begin{array}{c}4 \cdot 59 \pm 1 \cdot 87 \\
65 \cdot 89 \pm 18 \cdot 01\end{array}$ & $\begin{array}{l}29 \\
29\end{array}$ & $\begin{array}{l}\text { NS } \\
\text { NS }\end{array}$ \\
\hline
\end{tabular}

Table 5 Mean $( \pm S D)$ saliva sIgA and SC distribution in AS patients correlated with serum ESR and CRP levels. Group A: ESR $<15 \mathrm{~mm} / \mathrm{h}, C R P<0.50 \mathrm{mg} / 100 \mathrm{ml}(5 \mathrm{mg} / \mathrm{l})$. Group B: ESR $>15 \mathrm{~mm} / \mathrm{h}, \mathrm{CRP}>0.50 \mathrm{mg} / 100 \mathrm{ml}$ (5 mg/l).

\begin{tabular}{|c|c|c|c|c|c|}
\hline \multirow[b]{2}{*}{$\begin{array}{l}\text { Parotid } \\
\text { secretion }\end{array}$} & \multicolumn{2}{|l|}{ Group $A$} & \multicolumn{2}{|l|}{ Group B } & \multirow[b]{2}{*}{$\begin{array}{l}\text { Statistical } \\
\text { significance }\end{array}$} \\
\hline & $M e a n \pm S D$ & $\begin{array}{l}\text { Number of } \\
\text { estimations }\end{array}$ & $M e a n \pm S D$ & $\begin{array}{l}\text { Number of } \\
\text { estimations }\end{array}$ & \\
\hline $\operatorname{sIgA}(\mathrm{mg} / \mathrm{dl})$ & $3 \cdot 76 \pm 1 \cdot 22$ & 12 & $5 \cdot 48 \pm 2 \cdot 00$ & 15 & $\begin{array}{l}\mathrm{P}<0.02 \\
t=2.60\end{array}$ \\
\hline$S C\left(d^{2}\right)$ & $58 \cdot 65 \pm 11 \cdot 58$ & 12 & $71 \cdot 70 \pm 19 \cdot 19$ & 15 & $\begin{aligned} \mathbf{P} & =0.05 \\
t & =2.06\end{aligned}$ \\
\hline
\end{tabular}

SI conversion: $\mathrm{mg} / \mathrm{l}=\mathrm{mg} / \mathrm{dl} \times 10 . \quad \mathrm{d}^{2}=$ Diameter squared. 
Table 6 Klebsiella spp. $(\mathrm{Kl})$ carriage in normal controls and $A S$ patients correlated with clinical disease activity over a 2-month period

\begin{tabular}{lrrl}
\hline & $K l(+)$ & $n$ & Per cent. \\
\hline Normal controls & 15 & 29 & 51 \\
Active (AS patients) & 3 & 6 & 50 \\
Probably active (AS patients) & 12 & 21 & 57 \\
Inactive (AS patients) & 1 & 5 & 20 \\
Total (AS patients) & 16 & 32 & 50 \\
\hline
\end{tabular}

$( \pm 2 \cdot 05) \mathrm{mg} / 24 \mathrm{~h}$ compared with $2 \cdot 53( \pm 1 \cdot 24)$ $\mathrm{mg} / 24 \mathrm{~h}$ in controls, and the difference was not statistically significant.

\section{BACTERIOLOGY}

Thirty-two patients provided 87 faecal specimens, of which $26(30 \%)$ gave positive cultures for Klebsiella spp. compared with 23 out of $79(29 \%)$ of the specimens from the 29 controls. 16 patients $(50 \%)$ and 15 controls ( $51 \%$ ) had Klebsiella spp. isolated from the faeces on at least one occasion over the 2-month period of the survey. Clinical disease activity and faecal klebsiella carriage are compared in Table 6.

AS patients with raised serum ESR and CRP were divided into 2 groups according to their klebsiella carriage and were compared for their serum immunoglobulins and $\mathrm{C}_{3}, \mathrm{C}_{4}$ concentrations. Serum mean IgG and IgA, especially IgG, was higher and $\mathrm{C}_{4}$ was lower in the klebsiella-negative group than in klebsiella-positive individuals, but the difference was not statistically significant (Table 7).

No mid urine specimens showed any significant bacterial growth.

$\beta$-haemolytic streptococcus was isolated from the throat of 1 of the patients and 2 of the controls There was no significant change in immunological estimations of these cases.

\section{Discussion}

Raised Serum $\operatorname{IgG}, \operatorname{IgA}$, and $\mathrm{C}_{4}$ levels in AS patients, especially in those with raised serum ESR and CRP levels is in keeping with the findings of previous studies. ${ }^{11-13}$ There was also a significant rise in serum $\mathrm{C}_{3}$ in our study. A good correlation between raised values of serum ESR, CRP, and disease activity has been shown in AS patients. ${ }^{26}$ Mean serum $\operatorname{IgA}$ in patients with raised serum ESR and CRP was greater than in those with lower values. Mean serum IgG and $\mathrm{C}_{4}$ levels were raised in patients with a raised ESR and CRP, but these differences were not statistically significant.

None of the patients or the controls had SIgA deficiency. Mean saliva SIgA was slightly higher in AS patients than in controls. More strikingly, however, patients with raised serum ESR and CRP levels had statistically significant higher levels of saliva sIgA than those with low levels of acutephase proteins. Moreover, the same group of AS patients with high $\operatorname{sIgA}$ in their saliva had significantly high mean serum IgA correlated with disease activity. None of the AS patients showed any difference in their mean urine sIgA compared with controls.

We have found a similar overall frequency of Klebsiella spp. carriage in AS patients compared with controls. Positive cultures for Klebsiella spp. were more frequent in AS patients who had clinically active disease $(50 \%)$ than in patients with inactive disease $(20 \%)$, but the latter represents only 1 of 5 patterns. A comparison of klebsiella carriers and klebsiella-negative patients in an active phase showed no significant difference between the immunological findings of the 2 groups.

It may be concluded that the raised serum $\operatorname{IgA}$ in AS patients comes from gut mucosa, which strongly suggests, klebsiella or not, an antigenic triggering agent from the gastrointestinal system in AS patients. Raised serum IgG levels suggest further systemic antibody response as well as a local immune response in these patients.

We are grateful to Mr Ian Bolderson for expert technical assistance and to the late Mrs Jill Battersby for secretarial assistance.

\section{References}

1 Romanus R. Pelvo-spondylitis ossificans in the male and genito-urinary infection. Acta Med Scand 1953; Suppl 280.

2 Mason R M, Murray R S, Oates J K, Young A C. Prostatitis and ankylosing spondylitis. $\mathrm{Br} \operatorname{Med} J$ 1958; i: 748-51.

Table 7 Serum mean ( $\pm S D$ ) IgG, IgA, and $C_{4}$ levels in AS patients with raised serum ESR, and CRP levels and Klebsiella spp. distribution

\begin{tabular}{|c|c|c|c|c|c|}
\hline \multicolumn{3}{|c|}{$K I(+) A S$ patients } & \multicolumn{3}{|l|}{$K I(-) A S$ patients } \\
\hline Serum protein & $M e a n \pm S D g / l$ & Number of estimations & $M e a n \pm S D g / l$ & Number of estimations & Statistical significance \\
\hline $\begin{array}{l}\text { IgG } \\
\text { IgA } \\
\mathrm{C}_{4}\end{array}$ & $\begin{array}{r}13.91 \pm 9.25 \\
3.16 \pm 1.70 \\
0.45 \pm 0.14\end{array}$ & $\begin{array}{l}8 \\
8 \\
8\end{array}$ & $\begin{array}{c}18 \cdot 06 \pm 10 \cdot 15 \\
3 \cdot 34 \pm 1 \cdot 16 \\
0.29 \pm 0.10\end{array}$ & $\begin{array}{l}8 \\
8 \\
8\end{array}$ & $\begin{array}{l}\text { NS } \\
\text { NS } \\
\text { NS }\end{array}$ \\
\hline
\end{tabular}


${ }^{3}$ Catterall R D, Perkins E S. Uveitis and urogenital disease in the male. Br J Ophthalmol 1961 ; 45: 109-16.

4 Wright V, Catterall R D, Cook J B. Bone and joint changes in paraplegic men. Ann Rheum Dis 1965; 24: 419-31.

5 Ebringer R W, Cawdell D R, Cowling P, Ebringer A. Ankylosing spondylitis: klebsiella and HLA B27. Rheumatol Rehabil 1977; 16: 190-6.

6 Ebringer R W, Cawdell D R, Cowling P, Ebringer A. Sequential studies in ankylosing spondylitis: association of klebsiella pneumoniae with active disease. Ann Rheum Dis 1978; 37: 146-51.

7 Warren R E, Brewerton D A. Faecal carriage of klebsiella by patients with ankylosing spondylitis and rheumatoid arthritis. Ann Rheum Dis 1980; 39: 37-44.

8 Eastmond C J, Willshaw H E, Burgess S EP, Shinebaum R, Cooke E M, Wright V. Frequency of faecal klebsiella aerogenes in patients with ankylosing spondylitis and controls with respect to individual features of the diseease. Ann Rheum Dis 1980; 39: 118-23.

${ }^{9}$ Schlosstein L, Terasaki P I, Bluestone R, Pearson C M. High association of an HLA antigen, W27, with ankylosing spondylitis. $N$ Engl J Med 1973; 288: 704-6.

10 Brewerton D A, Hart F D, Nicholls A, Caffrey M, James D C O, Sturrock R D. Ankylosing spondylitis and HL-A 27. Lancet 1973; i: 904-7.

11 Kinsella T D, Espinoza L, Vasey F B. Serum complement and immunoglobulin levels in sporadic and familial ankylosing spondylitis. J Rheumatol 1975; 2: 308-13.

12 Nikbin B, Brewerton D A, Byrom N, et al. Lymphocyte function in ankylosing spondylitis. Ann Rheum Dis 1975; 34: suppl 49.

13 Christiansen F T, Hawkins B R, Dawkins R L. Immune function in ankylosing spondylitis and their relatives; influence of disease and HLA B27. Clin Exp Immunol $1978 ; 33: 270-5$.
14 Thompson R A, Asquith P. Quantitation of exocrine IgA in human serum in health and disease. Clin Exp Immunol 1970; 7: 491-500.

15 Heremans J F. The IgA system in connection with local and systemic immunity. In: Mestecky J, Lawton A R, eds. The Immunoglobulin A System. New York: Plenum Publishing Corporation, 1974: 45: 3-11.

16 Tomasi T B. Secretory immunoglobins. $N$ Engl J Med $1972 ; 287$ : 500-6.

17 Hanson L A, Brandtzaeg P. In: Stiehm E R, Fulginiti V A, eds. Immunologic Disorders in Infants and Children. Philadelphia: Saunders, 1973.

18 Heremans J F. In: Sela M, ed. The Antigens. New York: Academic Press, 1974; 2: 365.

19 Bennett P H, Wood P H N. In: Bennet P H, Wood P H N, eds. Population Studies of the Rheumatic Diseases. Amsterdam: Excerpta Medica, 1968: 456.

20 Curby W A. Device for the collecting of human parotid saliva. J Lab Clin Med 1953; 41 : 493-6.

21 Hobbs J R. Simplified Radial Immunodiffusion. Association of Clinical Pathology Broadsheet 68, April, 1970.

22 Oon C H, Lee J A. A controlled quantitative study of parotid salivary secretory IgA-globulin in normal adults. J Immunol Methods 1972; 2:45-8.

${ }^{23}$ Mancini G, Carbonara A O, Heremans J F. Immunochemistry $1965 ; 2$ : 235-54.

24 Beinenstock J, Tomas T B. Secretory $\gamma$ A in normal urine. J Clin Invest 1968; 47: 1162-9.

${ }^{25}$ Cooke E M, Brayson J C, Edmondson A S, Hall D. An investigation into the incidence and sources of klebsiella infections in hospital patients. J Hyg 1979 82: 473-80.

${ }^{26}$ Cowling $P$, Ebringer R, Cawdell D, Ishii M, Ebringer A C-reactive protein, ESR, and klebsiella in ankylosing ${ }^{+}$ spondylitis. Ann Rheum Dis 1980; 39: 45-9. 